\title{
Pursuing the Homeownership Dream in Shanghai: The Significance of House and Home in Migrant Families' Quest for Middle Class
}

\author{
Arianna Ponzini* \\ Research Fellow, TOChina Hub University of Torino, Italy
}

Submission: February 12, 2020; Published: February 26, 2020

"Corresponding author: Arianna Ponzini; Research Fellow, TOChina Hub University of Torino, Campus Luigi Einaudi, Lungo Dora Siena100, Torino, Italy

\begin{abstract}
This article investigates ideas of house and home in relation to status and class ambitions focusing on a widely overlooked but greatly relevant social group: aspiring middle-class domestic migrants with rural origins. The main argument is that processes of social mobility and the urbanization of the migrants parallel the processes of acquiring homeownership and of the house becoming home (through decoration, for example). The quest for middle-class status as well as middle-class reproduction of the family are achieved through house and networks, two elements that are closely connected. The analysis in this article proceeds in three subsections to examine the key themes of: entitlement to property, the symbolic consumption of house-related items and network reinforcement through the home. The first subsection compares renters and owners, in order to demonstrate why owning a home is key for migrant families in Shanghai who are pursuing middle-class reproduction. Subsequently, the second subsection looks at how middle-class identity and social distinction are achieved through consumption and home decoration choices. Ultimately, the third subsection shows how migrant families can achieve social status through family and networks by purchasing a home.
\end{abstract}

Keywords: Society; Social sciences; Domestic migrants; Economic; History; Culture; Income and wealth; Education; Political science

\section{Introduction}

In today's China, most urban couples are pursuing the homeownership dream: the country's homeownership rate has, in fact, remained stable at 90\% since 2012 (Peking University Institute of Social Sciences, 2017). Between 1998, when the central government announced the end of welfare housing, and by the time of the 2005 census, China had become the largest home owning society in the world D Davis [1]. Starting from Deng Xiaoping's reforms in 1978, private real estate has been an important engine for the country's economic growth and a symbol of status and financial success for the general population. In this new environment of privatization and individual property rights, every Chinese household had permission to dream of home ownership and to view their homes as their own private space where they could display family and individual prestige D Davis [2]. Furthermore, homeownership was soon aligned with ideas of class-consciousness and mediated through the mass consumption of visual and material culture: newspapers, magazines, catalogues, television and the internet are all part of the global marketplace where people shop for houses, furnishings, and ideas and values of family life [3]. Historically, the construction of the home as an expressive form has been associated with the consolidation and formation of the middle-class identity. The house and its interior decoration elements are, in fact, used as a form of self-presentation, a way to codify an image of oneself to others through the appropriation of the material environment [3]. In contemporary China, house and decoration choices play an important role both in constructing individual or family identity and in stating a household's social status. In the case of middle-class migrant families, purchasing a home in the city is seen as necessary for achieving a full urbanization of the individual and of the family. This is because home ownership confers a sense of stability and belonging to the new urban environment, at the same time enabling the migrants to express a personal image of respectability and success.

The present article advances a new framework for analyzing the social mobility of domestic migrants, which centers on home owning and on the process of the "house" becoming a "home". I ar- 
gue that home owning affects and reflects migrant families ${ }^{11}$ quest for securing middle-class belonging and social status in Shanghai. Building on previous work that focuses on rural to urban migration and class formation among urban Chinese youth, the present research study shows that, in contemporary China, the house stands at the center of a hierarchy of privileges in middle-class consolidation processes, especially for the aspiring middle-class rural migrant social group. This study contributes to research that studies rural to urban migration in China by looking at a social group that has been widely overlooked, i.e. aspiring middle-class migrants with rural origins, and to research that examines class distinction by placing homeownership at the center of class-related hierarchies of privilege. I argue that house, as well as ideas of home, is key in middle-class consolidation and reproduction processes, as it is the principal asset that confers class-related legitimation and power, and that it is able to provide both inter-class and intra-class distinction.

As a theoretical basis to support my argument, I avail myself of the Bourdieusian approach, which provides an effective definition of class and social mobility based on the relational aspects of class membership, as well as the concepts of distinction and class symbolic boundaries, both of which are key to understanding class-related dynamics in contemporary China. According to Bourdieu, social class refers to the position of individuals in a given social space, a system of objective determinations related to the socalled "class habitus", or socially constructed dispositions which are class-specific [4]. When determining class identity, a central element is class difference awareness: what differentiates one class from another are the economic and symbolic boundaries between different social classes. Such boundaries are essential as they provide each social class with specific elements of "distinction" [4] In this analysis, for instance, aspiring middle-class migrant families aim to secure a place in the middle class by keeping economic and symbolic distance from the urban working class or, more particularly, from other rural migrants to the cities. When analyzing class differences, income and wealth alone are not enough to determine class identity and membership. Therefore, Bourdieu identifies four different types of capital that are sources of power and socially valued as important elements of class distinction: economic capital (income and wealth), cultural capital (education, language and taste), symbolic capital (status and consumption patterns) and social capital (networks) [4]. The research question that lies at the basis of this study is: "What are the significance and implications of home owning for aspiring middle-class migrant families?" My efforts to answer this question were guided by two key concepts: social distinction and capital convertibility. Social distinction is essential for individuals to secure middle-class status belonging and derives from the presence of strong symbolic boundaries that discern and separate the middle class from the lower classes. My data shows that one of the strongest assets that middle-class families need to obtain in order to achieve their social distinction is a house. A house is not only linked to economic capital; most of all it allows for conversion into other forms of capital [4]: symbolic (i.e. status), social (creation of strong networks based on class belonging) and cultural (allows middle-class youth to attend quality schools).

So far, much of the literature on migrants and housing in contemporary China has dealt with the challenge's migrants face in the new urban environment. Numerous studies have investigated the hùkǒu system ${ }^{2}$ and its inequalities [5-7]. Other studies have looked at migrants' experiences from a psychological point of view, highlighting migrants' struggles in recreating their social identity in a new urban context [7-10]. Other relevant studies have focused on housing policies for migrants [11-13], migrants' accommodation issues, housing preferences and consumption patterns, and the channels used by migrants to find a house $[12,14,15]$. There has also been considerable treatment of the Chinese housing market, as well as of the social implications of owning a house in contemporary Chinese society $[1,2]$. Separate studies [3,16-19] have dealt with the middle class in China and what it means to belong to the middle class in contemporary Chinese society. Other scholars have analyzed the rise of the middle class and its social as well as political implications [16]. Other studies have looked at the Chinese middle class in relation to housing. $\mathrm{L}$. Tomba [20] has analyzed Chinese neighborhood planning as a way for the Chinese government to achieve social clustering and engineering. Enclosed residential neighborhoods are, in fact, a means for the government to promote ideas of social distinction as well as to encourage the pursuit of a higher sùzhì or "quality" by the middle-class residents, who serve the purpose of setting a social example for the general population. The ideas of sùzhì and social distinction, also in relation to the Chinese middle class, have been dealt with extensively [21-25]. Lastly, L Zhang [15] has extensively investigated the new homeownership and living revolution that

${ }^{1}$ For in-depth studies on the new Chinese middle class, please refer to D Miller 2001; C Li 2010; D Goodman 2014; Miao, $2016,2017$.

${ }^{2}$ The household registration system in force in mainland China, where each individual is registered as belonging to a specific area, including the categorization of "rural" or "urban". Non-local hukou holders often do not share the same welfare-related privileges as their local counterpart. 
has hit middle-class professionals and entrepreneurs in search of their own private paradise in Chinese society, which is now dominated by consumerism. The author has also looked at how housing is the key to achieving both material comfort and social distinction for Chinese families. However, there are no studies so far that have placed house and home owning at the center of migrant families' social advancement and middle-class pursuit in an urban setting. The present study will address this lacuna. As for methodology, this study is the result of qualitative field research conducted in Shanghai from September 2015 to June 2016, where I held repeated in-depth interviews and participant observation with the members of eleven aspiring-middle families (including extended family members). Although I do not go into the qualitative and ethnographic methodological details in this article, I wish to hereby provide an overview as for data collection and qualitative methods applied. The main research method used to analyze the data was grounded theory, which provides a methodology that allows the concerns of the social participants to emerge in context [26] and is thus useful for research of a social nature. In order to answer my research questions, I used a variety of data collection strategies, which I adapted throughout the ten months of fieldwork in order to obtain data which were significant, personal and relevant for this study. Along with face-to-face formal interviews, I used other more informal means of data collection, such as guided conversations in informal settings, e-mail exchanges, video-calls and voice-messages. The selection of such a varied range of data collection approaches mainly derived from the personal rapport I built up with the participant families, who expressed a desire to share personal experiences and thoughts with me through more informal means of communication as well. During my formal faceto-face interview meetings, I relied on semi-structured interviews, participant observation and a memo, and I have recorded these interviews both in oral form on a recording device and in written form in my fieldwork diary. To analyze my data, I transcribed and summarized all of the audio-recordings and field notes and then grouped the data into core categories, common categories and lower level concepts. This process allowed me to organize my findings in preparation for theory building and to identify the core themes which would constitute the heart of the findings in this present article.

In line with the major categories identified during the data categorization process, this article is organized around three key dimensions to how home owning can affect a family's pursuit and/or affirmation of class identity. The first dimension is entitlement to property, which indicates the family's social status and class status in multiple ways, especially when it aspires to a middle-class reproduction of the household. The second dimension is symbolic consumption, or the idea that the symbolic nature of the material environment (specifically, the house and home décor choices) enables the family members to demonstrate their social status and affirm middle-class identity through consumption patterns and lifestyle. The third dimension is network reinforcement (in particular, at the household level), where the house is seen as a means of ensuring a stable middle-class reproduction of the family in the long run, as well as of reinforcing family networks. Home owning, in fact, can affect family dynamics and, consequently, a nuclear family's journey towards securing middle-class belonging and the ability to sustain reproduction. These three dimensions, property, home-related consumption and networks represent the three essential components of a dwelling: the house (property), the home (chosen decorative elements) and the family (kinship networks). This study examines the aforementioned three dimensions in turn, also incorporating interview extracts within the narration in order to give voice to the participants' experiences and aspirations.

\section{Entitlement to Property: The Status of Renters and Homeowners}

"Purchasing a house in this city seems like an unreachable goal for many Chinese families, especially for those who do not possess a local hùkǒu. Non-local residents are cut off from the bank loan system and, although economic means can seem like a sensible solution to the problem, Shanghai's sky-high real estate prices are a huge obstacle for most migrant families like ours." This observation by Mrs Mao confirms that in order to succeed in the home owning middle-class urban dream migrant families must possess enough economic capital to afford such a costly investment. A small minority of my aspiring middle-class participants owned a house (three migrant households), and all of those who did not constantly complained about the prices of Shanghai's housing market, which also requires migrant purchasers to have worked in the city for a total of five years. Mrs Mao went on to explain that: "The amount of pressure that this situation puts on the shoulders of migrant families is huge. Due to hùkǒu-related regulations, the only possible way for middle-class migrants to buy a house is by obtaining a salary increase, or by patiently waiting to have saved enough money to buy a family home."

In fact, a salary increase and/or a job promotion are a stepping-stone to a higher social status, which also implies the creation of new and more prestigious - and therefore powerful - networks, which can come in handy in the process of house purchasing. It goes without saying that for working-class, lower-status migrants it is nearly impossible to afford housing in Shanghai; therefore, middle-class families and individuals try to avoid falling back to a lower status at all costs. An owned home can affect a family's class and social status in many ways. First, an owned home facilitates a 
family's urbanization process, as a house is a very important step in the quest to securing belonging to the Chinese middle class and to a fully urbanized life with strong social networks. Home owning is, therefore, closely connected not only with status and class but also with an individual's or a family's sense of belonging to the city by creating roots. A home is essential for the formation of a sense of belonging; however, as Mrs Liang stated, "it is only after you introduce your own style and design that you can call a home your home". This feeling of freedom of making changes to a home so that it fully reflects a family's own style is often only possible for homeowners, as opposed to renters.

An owned home also confers a sense of stability. In contemporary China, renting a house, as opposed to owning one, is generally felt to be a much less stable and desirable option. Furthermore, if it is true that the house is an external projection of the Self and, therefore, it reflects the individual's identity [3], a rented home reflects the image of a temporary resident. The concepts of temporariness and permanence, which are linked to renting and owning, respectively, are also closely connected to a family's class position, as well as to social reproduction and advancement towards the desired standard of the middle class. For a migrant family, a permanent home is of great importance for the reproduction of its middle-class status, since owning an urban home can also affect the future of the family's children, mainly in terms of education and prestige, and provide a secure foothold in the city. On the other hand, renters do not enjoy the same social stability as owners do: they live in a precarious present (let alone their future prospects or the social reproduction and advancement of the family) and are perceived as temporary residents, or even outsiders. An owned house further affects a family's social status and networks as it allows families to be considered as "local", which is fundamental for the acquisition of social status and prestige: the local "Shanghainese", in fact, are perceived as being of a higher quality than non-local citizens. The label “外地人” (wàidìrén) can be associated with ideas of rootlessness, temporariness and out of placeness, unlike the “上海人” (Shànghăirén), who are perceived as having a natural right to claim a sense of belonging to the city [9] Mrs Ye explained: "As far as middle-class migrants are concerned, the difference between 外地人 (wàidìrén) and 当地人 (dāngdìrén), i.e. 'the local residents', is still present. However, these two groups are not fixed and immutable. The Shànghăirén group can be divided into at least three categories: wàidìrén, who have lived in Shanghai for years; second generation Shànghăirén (born and raised in Shanghai, but born from wàidì parents); and 老上海人 (lăo Shànghăirén), those who belong to ancient Shanghainese families." Purchasing a house is a very important step towards being viewed as a Shanghai resident, as an individual or a family who belongs to the city of Shanghai. My respondents were aspiring middle class and most of them were highly educated: "We are not any different from the local middle class in terms of quality. But until we show them, we belong here, we will always be labeled as wàidìrén," Mr Deng concluded.

It is clear that a shift of the home from one's rural hometown to Shanghai is beneficial to the families because it affects a family's sense of belonging and upward mobility, while temporariness is an enemy of social development and status. However, both individual/family identity and place identity are complex and dynamic concepts, multiple and unfixed, as well as relational [9,27]. This is why integration and permanence are very important for the formation of a family's urban identity, since permanence facilitates the process of network creation. For temporary residents, not only is this process harder to achieve, but the networks around them are also a reflection of their own precarious lives, and therefore such networks contribute less to the social advancement of the family [23]. Apart from establishing a sense of belonging, owning property can also boost an individual's sense of confidence, not only because s/he can identify with a valuable asset, but also because such a purchase implies economic success and personal achievement. All these feelings are closely connected with concepts of face and respectability. By contrast, renters feel the constant pressure of not being able to purchase a family home and experience this pressure as a personal failure toward the family. This is especially the case among men since in Chinese families it is the male members who traditionally bear the responsibility of providing for a family home. Renters feel a huge amount of pressure, especially when they are thinking about starting a family or already have small kids, as house and education are closely connected in China.

In China, the purchase of a house usually occurs during key transitional moments in life. In fact, individuals mainly buy houses concurrently with the following life events: marriage, birth of the first child, and a child starting school (in China, you can send your child only to the neighborhood school; therefore, it is a normal practice to move to a neighborhood that is known for having a good school). The social norm of buying a home shortly before or after marriage is so strong that a couple getting married without first buying a home is said to have a "naked marriage" (裸婚, luòhūn). As purchasing a house corresponds to certain life events, friends' and families' expectations are also an important element to consider when analyzing the issue from the perspective of social status. Not satisfying the expectation of having the means to purchase housing for one's family may cause an individual to lose face, while satisfying such expectations can lead to an increase in social status. The story of one of the families (the Shi family) I visited casts light on how expectations can affect an individual's rep- 
utation among the family. "My husband, originally from rural Anhui, was not able to meet my parents' expectations of purchasing a house after the wedding. Eventually, my parents 'solved the situation' by securing a house for us in Shanghai, while my husband put in a considerable amount of money for the complete renovation of the property. In spite of his financial efforts, my family never fully accepted the fact that he was not able to purchase a home for his new family, and he is seen by them as low in quality, 素质低 (sùzhì dī), and with no sense of 'face' and responsibility."

This event clearly affected Mr Shi's relationship with his family and extended family.

Another important advantage that home owning provides relates to hùkǒu. Many consumers who do not have a hùkǒu household registration in the city wish to buy a home so they can obtain more hùkǒu-related rights, such as their child being allowed to attend a public school and eventually take the university entrance exams locally, or to receive heavily subsidized healthcare. Owning a house is even more important for migrants with rural origins who are struggling to secure middle-class belonging and are facing the fear of falling back into disadvantaged class groups: a house, in fact, confers many social and financial advantages, all of which contribute to gaining face, status and security. Therefore, renters have far more disadvantages than homeowners and feel all the pressure of not being able to secure a stable and prestigious future for their family.

\section{Symbolic Consumption}

Status, house and home

\section{Homeownership and status}

"In contemporary China, greeting a friend with questions such as: 'Have you bought a house yet?' is not an uncommon practice, which also demonstrates how housing is nowadays considered one of the primary assets in judging an individual's well-being, especially that of Chinese men. Purchasing property is also closely connected with marriage, due to the principle that one of the main conditions for marriage is the man's wealth - the principal reflection of which is housing." As the words of Mr Tong suggest, in Chinese culture the house carries great symbolic meaning. Home ownership is, first and foremost, a clear status indicator, and therefore non-homeowners are often perceived to be part of the lower class, as opposed to the aspired middle class. The main reason for purchasing property may not be the same for everyone, but my fieldwork with migrant families in Shanghai clearly shows that Chinese people purchase housing to satisfy three main pur- poses: 必需品 (bìxūpǐn), necessity, 面子 (miànzi), face (symbolic), and投资方式 (tóuzī fāngshì), investment (economic), with these purposes reflecting and producing class status.

In one of our conversations, Mr Liang told me:

"Individuals who purchase housing for necessity are often referred to as 刚需族 (gāngxū zú) or 'group of people who buy a house for mere necessity'. This group sees home owning as a need: it is a way to secure one's foothold in the city and gain a 'feeling of safety', 安全感 (ānquán găn).”

As Mrs Tong explained, face is a further purpose that purchasing a house can help to satisfy.

"A saying in China goes: 'because one needs face in death one endures wrongs in life' (死要面子活受罪, sǐ yào miànzi huó shòu zuì). This means that Chinese people cannot let others look down on them up to the point of often lowering the quality of their own life. In Chinese culture, it is essential to gain others' respect, to have others say to you that 'you have face' (有面子, yǒu miànzi)". Individual identity is often projected onto material objects and possessions: you are who you are because of what you have. The image created of oneself may be more important than the real Self. As famous actor and director Feng Xiaogang once noted, in China many residential neighborhoods and buildings have foreign names, such as "California waterfront", or they use words such as "exotic notable community", "French garden" and "Mediterranean style", but it is hard to imagine there would be a "Suzhou" neighborhood in Western countries ${ }^{3}$. He was pointing out that many Chinese real estate agents and developers use foreign names to appeal to Chinese consumers' "face" psychology and give them face, “给面子” (gěi miànzi). The director’ s words depict a realistic image of the housing market in contemporary China, showing how ideas of status are strongly connected to ideas of home and house, which perfectly align with the popular saying: "No purchase of house, no purchase of face”, “买房子就是买面子” (mǎi fángzi jiùshì măi miànzi). As previously stated, there are certain possessions that confer more status on individuals than others. Clearly, in contemporary Chinese society the house is one of the most powerful, if not the most powerful, means for the creation of a respectable image of oneself.

As mentioned above, in China a house carries a lot of meaning, so that Mrs Mao admitted:

"When looking for a wife, if future parents-in-law ask the man if he owns a house, if he answers yes or no the impression of him is not the same. When moving to the city, renting a house instead

${ }^{3}$ See, for example, https://www.guancha.cn/culture/2013_09_26_175045.shtml (Chinese) 
of owning it clearly affects other people's perception of that individual. When asked if one owns a house in the center or in the suburbs of the city, the answer will affect that individual's status and reflect on their 'face'." Nowadays, housing prices are sky-high, but individuals and families still want to purchase a house, and they want a house that is "respectable", although they are already living in one.

Real estate is also a preferred channel of investment: whoever does not own a house wants to purchase one, and whoever owns one wants to purchase more. A house is a very powerful possession: the number of houses and the location of one's own property contribute to the individuals' social status. Furthermore, as Mr Mao explained: "Chinese consumers have very few places to invest their money, so most people invest in a house, which is the most valuable family asset and worth much more than income alone." A house, therefore, can directly affect a family's economic and symbolic capital, both of which are elements that define middle-class identity and status. The acquisition of status is especially important for migrant families who come from disadvantaged backgrounds, as it is a means to secure a place in the urban middle class.

\section{Home-décor and Status}

The analysis has focused until now on how owning property together with the location of the property can affect an individual's or a family's social image. However, the concept of face is also connected to interior decoration and to the choice of furniture, both of which contribute to a family's social status. If it is true that a house is the material projection of a family's image and status, this is also true for the objects that are inside the home: "When a guest walks into a home, what s/he sees is the image that the family wishes to convey to others," Mrs Wang explained. Interior decoration is, in fact, a public display of personal belongings: it affects social relations and establishes relations with an ideal outside world. A home's decorative elements represent an important insight into a family's identity, indicating social aspiration, material comfort and lineage. Such elements also serve the important purpose of class consolidation, in that domestic objects are indicators of social distinction. Material identity is, in Chinese society, as important as personal identity.

The importance of interior decoration and its connection to status is a somewhat recent idea in Chinese society. It was only following Deng Xiaoping's privatization reforms that houses and homes started to provide an important insight into a Chinese family's status and social position [2]. Families learned that housing and home decoration played a pivotal role in defining their social identity; however, the way they display their family prestige has changed widely over the years. From the beginning of Deng Xiaoping's era through the 1980s, the general attitude towards home decoration was that of modesty. Home decoration details such as curtains or parquet floors were often avoided, considered as extravagant. However, by the 1990s men and women started to use their homes to display their social status, financial success and cultural sophistication. Furthermore, home decoration magazines started to circulate, bookstores devoted entire sections to interior decoration, and even the government devoted an evening show to home renovation. Great importance was given to good taste, which families had the chance to display in their homes [2]. In the light of all these changes, new landscapes of living emerged. If home buyers in the 1980s focused almost entirely on the house as a physical space, today urban residents look for more: a green neighborhood, cultural taste and new lifestyle aspirations. These new emerging concepts of living are another consequence of private home ownership: a domestic space, apart from displaying a family's social status and wealth, is also an indicator of cultural refinement and life orientation [2]. Within Chinese homes, more specifically those of my participants, it is possible to identify certain key decorative elements that are perceived as prestigious. These elements are usually either of high economic value or else they belong to traditional Chinese culture. In my many visits to migrants' homes, I had numerous opportunities to see their choices for decoration and their taste in ornamental objects. Chinese families often display their most precious belongings together with family portraits, in order to convey an idea of a well-off and happy family. Such objects include traditional Chinese artifacts or even renowned foreign brands. Mrs Tong told me: "Nowadays, even furniture can 'have face' and may affect the image that the family conveys and how the family is perceived by others. It is common to find the label '有面 子的家具' (yǒu miànzi de jiājù), or 'furniture which has face', for what Chinese see as 'respectable' furniture, and it is common to find virtual enquiries on Baidu along the lines of: 'Does this piece of furniture "have face"?" This question, though, is difficult to answer because the qualities of the items that are necessary for a product to have face are subject to change.

"In traditional Chinese homes, the most precious element was wood", explained Mrs Mao. In Chinese home decoration, the prevalent type of wood used is mahogany, 红木 (hóngmù) in Chinese, or other dark-colored types of wood. In contemporary homes, “ 实木家具” (shímù jiājù), real wood furniture, is still considered very precious and is often labeled as a premium kind of "furniture which has face". In my participants' homes, wood was by far the most dominant furnishing. All homes had wooden floors and most pieces of furniture were made of dark wood. The best sofas are also made of dark brown leather to match the color of the furniture. 
When entering the families' homes, in addition to furniture, three other items struck my attention as important face-giving items: crystal lamps, precious tea sets and huge flat-screen TVs. "Most homes have yellow or pink crystal lamps, colors that have auspicious meanings in the traditional Feng Shui philosophy", Mrs Mao went on explaining. Furthermore, lighting is an important element in Chinese home decoration theories, as it is able to affect the mood of the family and even other aspects of the residents lives, such as their careers (TK Collins 1999). According to the theory of the Five Elements, yellow is associated with the element of 土 (tǔ), soil, which produces gold. Therefore, yellow lamps are believed to irradiate the home with wealth and good fortune. Pink and purple are also very popular due to the expression “招桃花” (zhāo táohuā), where "peach blossoms" refer to marriage. Each family has its own style, classical or modern, but crystal was a favorite material for lamps because the glittering and sparkly nature of crystal brightens up the domestic space, irradiating it with light and good fortune. Crystal is also known as "Feng Shui stone": each type of crystal represents a different frequency of energy and produces different magnetic fields. Therefore, in Chinese homes, lamps are often quite noticeable, and they are a piece of decoration that is usually proudly showed to the guests by whoever is in charge of the home tour.

Tea sets are a further important element in Chinese homes, as they refer to China's traditional culture and are a symbol of respect, 尊敬 (zūnjìng), of the country's ancient traditions. For five thousand years, tea culture has been the symbol of Oriental civilization, and it has always been deeply rooted in Chinese culture [28]. During Chinese traditional festivals, tea is served to family and guests as a symbol of blessing, longevity and gratitude. Tea sets are the closest "partner" of tea and symbolize respect for traditional culture, family and harmony. The quality of tea and tea sets are also closely linked to perceptions of a family's status and respectability. However, the most important item in an ideal Chinese living room is the television set: the bigger the set, the better it is for a family's "face". The TV is one of the forms of entertainment for visiting family and guests, and therefore it is often at the center of attention: as guests walk into the living room, the eyes go straight to the huge, flat-screen television. Therefore, choosing a fashionable and expensive TV is important for the image of the family, conveying the impression of wealth and economic power. This new way of living, which combines families, culture and status, informs emerging ideas about lifestyle today in China and highlights the importance of the home in the process of upward mobility of both individuals and families. In short, home décor directly affects a family's identity, class and social status as well as its networks.

\section{Network Reinforcement: Family Reunifications and Reunions}

The effects the migration processes have on the characteristics and dynamics of family structure, and on the family's class and status, are multiple and intertwined. Family becomes a central element within migratory networks and chains and plays a decisive role all the way from the start up to the integration of the family in the new context [29]. Migrants are widely affected by what surrounds them, not only on a macro-social level (economic, political and social contexts), but even more on the household level and in migratory situations; the place of destination often acquires a predominant role compared to the place of origin. This is true for China's rural-to-urban migrants especially, because moving to the city is the only way for individuals and families to achieve middle-class belonging. This fact explains why my participants were so strongly oriented towards embracing an urban identity and arranging their lives according to middle-class scripts of family life. The new urban context represents a priceless source of social advancement opportunities, which the original rural setting, as well as migrants' original rural identity, cannot provide. However, the process of adaptation to the new urban social scripts implies challenges and adjustment, both of which can be better overcome with the aid of a strong and present kinship network. Extended family, especially the parents of the couple, often plays a very important role in the nuclear family's dynamics. It is common for family reunification in the city to occur when the couple's first child is born. As Mr Mao explained: "Elderly parents are usually actively involved in the nuclear family life, from the wedding to the raising of the grandchildren. In Chinese families, it is common for grandparents to take care of the grandchildren while parents focus on work. When the elderly parents do not live in the same house as the couple, the couple usually goes to their house for meals. This way, the couple can focus more on their work." Therefore, a reunification and urbanization of the household is highly desirable as a way of providing accommodation for grandparents and the care for children that helps to secure the reproduction of the middle-class nuclear family. The fact that the whole family often plans to reside in the same house, or at least in a way that the parents live very close to the nuclear family's apartment, will often affect housing choices and the purchasing power of the nuclear family. If the house-hunting plan succeeds, the result will be an increase in the social status and in the family's social advancement in the long run. The Wang family, for example, is looking to purchase a house that would suit the whole household in view of the birth of the couple's first child. However, housing prices are impeding the realization of this goal in the short term. In such situations of family reunification, purchasing property is preferable to renting, not only in order to 
start climbing the property ladder for reasons of stability and a sense of belonging, but also for reasons of reputation. It can be argued that reunification is possible even in a rented home, but in China the perception of the nuclear family by the extended family is completely different with an owned home. Furthermore, as my interviews as well as informal conversations confirm, the "renting solution" is often criticized by the extended family and seen as a far from ideal solution, put into practice only because of the lack of a better alternative. Mrs Wang stated: "Achieving a full family urbanization by stably residing in an owned home in the city is a source of great pride and miànzi for the rural extended family, who views such an achievement as an important family accomplishment."

Another way owning a home in the city can affect a nuclear family's social status within an extended kinship network is by permitting the family to host extended family reunions, for example Chinese traditional festivals.

Many migrants return home infrequently, typically once a year during the Chinese New Year or Spring Festival. Processes of separation and reunion are pivotal to Chinese household and family dynamics, especially during calendrical festivals, such as the Chinese New Year [30]. Most times it is the migrant family that goes back to the village, but families with stable properties in the city often become hosts of New Year's celebrations, an event which is a great source of pride. Such processes of separation and reunion discursively construct identification with a certain place, which in this case means the formation of a sense of social belonging in the city of Shanghai [30]. This is why such rituals and celebrations represent a very strong statement for the family, highlighting the fact that the nuclear family has successfully reached an urbanization of its identity and is on the right path for securing a social reproduction of the family status, and possibly of the extended family as well. The frequency of family reunions depends on multiple factors, among which are social class and economic conditions. Being able to host extended family members in one's own home is also a way to facilitate family reunions and reinforce the family network, as confirmed by Mrs Shi:

“This year, we finally achieved our family's homeownership goals and purchased an apartment in the Minhang district. This achievement means a lot to our family and extended family, not only because it has brought us a great sense of security, but also because it has brought our family closer. My husband's parents and relatives live in a village in Anhui province, while my parents moved to Shanghai with us many years ago. The fact that our extended families live in two different places makes things a little complicated during Chinese traditional festivals, when families are expected to be together and celebrate under the same roof.
Up to this year, we have always alternated, spending one Spring Festival in Shanghai and one in Anhui. However, my mother has been having health issues for many years and it is not ideal for her to be away from home for long periods of time. Therefore, when we go to Anhui, my parents are alone in Shanghai. My husband and I have been thinking of having his family over to stay at our place during New Year's celebrations, but they never seemed to take our rented home too seriously and preferred to celebrate in their family home in the village. But now that we are homeowners, they have suddenly decided to spend the holidays in Shanghai. I was really happy and so were my parents: for the first time our families were reunited, and we spent one of the best Spring Festivals I can remember. "What emerges from Mrs Shi's story is that homeownership can have the power of making a family stronger and closer: her husband's family finally acknowledged her and her husband's status in the city, as well as their new urban identity and belonging. Furthermore, as seen in the previous chapter, migration can lead to an increase in social status and create a gap in miànzi with the left-behind family. An owned property in the city allows migrants to make a stronger statement in terms of difference in status and personal success, and it represents a stepping-stone to possible social advancement for the entire household. These interviews confirm that we are facing a different generation of migration: today, migration is an accepted path to a better life. It seems that many migrants are driven less by poverty and more by opportunity. Migrants also have looser ties to home and come and go according to personal schedule, not according to farming or lunar calendars. They are more ambitious and less content and there is a much stronger focus on career. Hùkǒu still remains important, especially once children are born, but many migrants agree today that there are other means to obtaining a better status, for example, by earning more money and purchasing a house. Increasing status, belonging to a strong middle class and achieving a stable life in the city are some of the main goals for these migrant families, and home owning is a very important step in achieving these goals.

\section{Discussion and Conclusion}

"What is the significance of house and home for aspiring middle-class migrant families?" was the main research question behind this research. The answer is that housing stands at the center of contemporary Chinese society's hierarchy of privileges, representing the nucleus around which middle-class consolidation and reproduction processes revolve. In the words of the families who took part in this project, the purchase of a family home brings class-related legitimation and power, which secures homeowners a strong place within the widely heterogeneous Chinese middle class. The subjects of this research all belong to the first genera- 
tion of a new middle class in China, a situation which makes both their collective and individual identities extremely uncertain: their identity, in fact, is not firmly rooted in a long, ongoing process of class continuity passed on from generation to generation [31]. The heterogeneity of the Chinese middle class $[17,18]$, as well as the precariousness of middle-class membership, is cause for the need to create strong symbolic boundaries to demarcate both intra-class and inter-class differences [4]. My analysis of the heterogeneity of the middle class, as evident also among my participant families, suggests that homeownership is a crucial factor in the production of class distinction. In fact, the two major categories of "homeowners" and "renters" among the Chinese middle class, which were described during my fieldwork interviews as respectively "exclusive" and "common", seem to interact in an interdependent symbolic relationship that contributes to determining meanings of class identity [4]. The result of this interaction is that homeownership is primary within processes of middle-class consolidation and reproduction owing to the fact that homeowners are entitled to invaluable social privileges to which renters do not have access, as shown in the preceding analysis. Furthermore, what allows aspiring middle-class individuals to secure distinction within such a precarious class group is the possibility of enjoying inclusions and exclusions that can limit or promote social mobility [20]. For the Chinese middle class, I argue that the strongest asset that allows for the most significant inclusions is the house. Indeed, as I have demonstrated throughout the article, the distinction and privileges that come with homeownership are narrow and exclusive [1]. This approach to understanding class membership and identity, which centers on the symbolic construction of inter-class and intra-class boundaries, provides insight into the relational aspects of class, as class is "something that in fact happens". Using Bourdieu's words, "class is not something given but something to be done". This is why aspiring middle-class migrant families work so hard day by day to build their future and to secure their place within the uncertain world of the Chinese middle class. For aspiring middle-class migrants, homeownership is key to securing urban belonging. Individuals and families with rural backgrounds met in Shanghai believe that purchasing a house is the principal way of gaining a sense of security in the city, both personal and in terms of social class, and of laying the foundations for a middle-class reproduction of the family. Middle-class membership is based on multiple factors, not on income alone: economic, cultural, social and symbolic capital all contribute to determine middle-class belonging [4]. The strongest asset that encompasses all of these species of capital is housing, which is why migrants use housing strategies to secure an urban middle-class identity. Homeownership brings together status, social class and networks, affecting middle-class migrants' urban experiences.
My analysis of class and status enhancement strategies suggest that access to housing has become a major discriminant between social actors and that it often determines social status more than income alone does. Housing is, therefore, a crucial element in class reproduction, and homeownership is a very powerful means of achieving social distinction, thus explaining the decision to place housing at the center of class reproduction analysis in contemporary Chinese society. This article has specifically investigated how middle-class identity can be affirmed through property, consumption and networks, which correspond to the essential components of a dwelling: house, home and family. An owned home can benefit a family's class and social status because it facilitates the urbanization of its identity and conveys an idea of permanence and stability to the Self and others, thereby benefiting the family's middle-class reproduction. A house also allows the family to be perceived by other Shanghai residents as "local" as opposed to outsiders, thereby strengthening its urban networks. An owned home provides the family, especially its male members, with a sense of security and achievement in fulfilling their responsibilities towards the family. A house also provides many hùkǒu-related rights. All these advantages that homeownership bring are evidently even more meaningful for wàidìrén with rural origins, who are struggling to secure a place in the city and in the new Chinese middle class. The significance of home owning is also particularly relevant for the members of this specific social group: they are educated and relatively well off, but they struggle because of social and institutional dynamics which cause them to worry about losing their newly acquired social status.

The brand of the home and the home décor are also an important part of a family's statement about its social status. Consumption and lifestyle are seen by families as a means of enjoying and securing middle-class identity and social distinction. When speaking of décor in China, the most prestigious elements are those which demonstrate the possession of high economic or cultural capital, important elements in the status discourse and in middle-class belonging. Therefore, home décor can affect the sense of Self and the social relationships which are formed or cultivated starting from the home. Class identity can also be negotiated and affirmed through social networks. An owned home can benefit the nuclear family's ability to negotiate and build social relationships in ways that help it sustain and build a middle-class identity. Many times, processes of migration involve the extended family, especially the nuclear family's parents, who represent a very valuable asset within a household's inter-generational dynamics. Furthermore, residing in a family-owned property in the city is perceived by kin and by social interlocutors as an important family achievement. Owing to ideas about status and personal realization, an owned home is able to attract the extended family to the city, instead of 
the nuclear family to the village. Being able to host celebratory dinners during traditional Chinese festivals further reinforces the family statement that it belongs to the urban middle class, which brings pride to the entire household while enabling it to elide village contacts and concentrate on urban ones instead.

In short, house, home and class status are closely connected and play an essential role in the strategies and experiences of aspiring middle-class migrant families, who perceive homeownership as the principal way of securing urban and middle-class belonging. Furthermore, owning a home plays a pivotal role in the process of adaptation to the city, shaping both the individual's and family's class identity and strategies for middle-class reproduction of the family in the long run. This article contributes to the literature on rural to urban migration in China by giving voice to a social group that has until now been widely overlooked: middle-class migrants with rural origins. China's contemporary social and economic relations have produced new social groups that are struggling to determine their identity [31]. However, the majority of relevant studies on rural to urban migration have focused their research on working-class migrants (农民工, nóngmíngōng), for the most part excluding middle-class migrants from the mosaic of the internal migration literature $[9,14,24,31]$. This evident gap in the China-related ethnographic literature on rural to urban migration has caused an elision of an important topic: housing aspirations among migrants.

Indeed, relevant studies that have dealt with working-class migrants have merely looked at accommodation strategies and challenges e.g. [12] due to the precarious economic conditions of the subjects. Therefore, the only literature that has investigated housing aspirations in contemporary Chinese society is the one that examines the Chinese urban middle class. It goes without saying that, although similarities exist between the urban middle class and the middle class with rural origins, homeownership for aspiring middle-class migrants with rural origins acquires different shades of meaning due to their disadvantaged background. Nevertheless, relevant literature on the Chinese middle class has associated ideas of class identity with middle class consumption patterns. As Tomba [20] clearly explained, although there are factors of individuality in class identity and formation processes, the middle class in China "appears to shape their status around a new set of collective interests", especially in relation to consumption and knowledge resources. When looking at the Chinese middle class, Zhang Li [15] also placed the focus of her analysis on consumption, dealing extensively with the interests of the middle class as homeowners. Further studies, such as those by D Davis [1], D Goodman [17] \& Y Miao [18], have also provided exhaustive analyses on the Chinese middle class by attempting categori- zations and definitions as well as by analyzing middle class consumption and homeownership patterns. The present study has integrated the two bodies of literature (rural to urban migration and middle-class studies) in order to share the perspectives of the social group comprised of middle-class migrants with rural origins within middle-class reproduction dynamics. Therefore, this article has provided a new framework for analyzing distinction and middle-class reproduction, while also contributing to a second body of literature that studies migration and urbanization dynamics in China. Ultimately, homeownership legitimates middle-class membership and brings power and privileges to the families who can achieve this dream. House and home, therefore, are key to accessing the privileges that promote social mobility and advancement and are central to middle-class identity consolidation and reproduction processes [32-34].

\section{References}

1. Davis Deborah (2006) Urban Chinese Homeowners as CaitizenConsumers. The Ambivalent Consumer, In: S Garon, P Maclachlan (Eds.), Cornell University Press, New York, US, pp. 281-299.

2. Davis, Deborah (2003) When a House Becomes His Home, Popular China. In: P Link, R Madsen, P Pickowicz (eds.), Rowman and Littlefield, United States, pp. 231-250.

3. Miller David (2001) Home Possessions, Berg Publishers, Oxford, United Kingdom.

4. Bourdieu, Pierre (1984) Distinction, Routledge, London, United Kingdom.

5. Fan Cindy (2003) Rural-urban migration and gender division of labor in transitional China. International Journal of Urban and Regional Research 27(1): 24-27.

6. Fan Cindy (2008) Migration, hukou and the City, China Urbanizes: Consequences, Strategies and Politics, The World Bank Washington D.C., United States.

7. Florence Eric (2006) Debates and Classification Struggles Regarding the Representation of Migrants Workers. China Perspective.

8. Jacka Tamara (2006) Rural Women in Urban China: Gender, Migration, and Social Change, Armonk USA, M E Sharpe Inc, 21(2): 353-355.

9. Sun Wanning (2009) Suzhi on the Move: Body, Place and Power, Positions: East Asia cultures critique 17(3): 617-642.

10. Sun Wanning (2014) Subaltern China: Rural Migrants, Media, and Cultural Practices, Rowman \& Littlefield, Lanham, United States.

11. Huang Youqing, Clark William (2002) Housing Tenure Choice in Transitional Urban China: a Multilevel Analysis. Urban Studies 39(1): 7-32.

12. Wu Weiping (2004) Sources of Migrant Housing Disadvantage in Urban China. Sage Journals 36(7): 1285-1304.

13. Shi Li, Hiroshi Sato, Terry Sicular (2013) Rising Inequality in China: Challenges to a Harmonious Society, New York, Cambridge University press, United Kingdom.

14. Zhang Li (2001) Strangers in the city: Reconfigurations of space, power and social networks within China's floating population. Stanford University Press, California, United States. 


\section{Annals of Social Sciences \& Management studies}

15. Zhang Li (2010) In Search of Paradise, Cornell University Press, New York, United States.

16. Li Chunling (2010) Characterizing China's Middle Class: Heterogeneous Composition and Multiple Identities. China's Emerging Middle Class: Beyond Economic Transformation, Cheng Li (edn.), Brookings Institution Press, Washington DC, USA, pp. 135-166.

17. Goodman, David (2014) Class in Contemporary China, Polity Press, Cambridge, United Kingdom.

18. Ying Miao (2016) Being Middle Class in China: Identity, Attitudes and Behavior, Routledge Studies on the Chinese Economy, London.

19. Ying Miao (2017) Middle Class Identity in China: Subjectivity and Stratification. Asian Studies Review 41(4): 629-646.

20. Tomba Luigi (2010) Gating Urban Spaces in China: Inclusion, Exclusion and Government. Gated Communities, London, Routledge, United Kingdom.

21. Anagnost Ann (2004) The Corporeal Politics of Quality. Public Culture 16(2): $189-208$

22. Fong Vanessa (2006) Only Hope: Coming of Age Under China's OneChild Policy, Stanford University Press, California, United States.

23. Kipnis Andrew (2006) Suzhi: A Keyword Approach. The China Quarterly 186: 295-313.

24. Hanser Amy (2008) Service Encounters: Class, Gender, and the Market for Social Distinction in Urban China, Stanford University Press, California, United States.
25. Zavoretti, Roberta (2016) Rural Origins, City Lives. Seattle, University of Washington Press, United States.

26. Charmaz Kathy (2006) Constructing Grounded Theory: A Practical Guide through Qualitative Analysis California, SAGE Publications Ltd, United States.

27. Massey Doreen (2005) For Space, SAGE Publications Ltd, London, United States.

28. Li Xiusong (1993) Chinese Tea Culture. The Journal of Popular Culture 27(2): 75-90.

29. Bonizzoni Paola (2009) Famiglie globali Le frontiere della maternità, Torino, Utet Università, Italy.

30. Stafford Charles (2000) Separation and Reunion in Modern China, New York, Cambridge University press, United Kingdom.

31. Woronow TE (2012) Class Consciousness, Service Work: youth and class in Nanjing vocational secondary schools. Journal of Contemporary China 21(77): 779-791.

32. Jacka Tamara (2009) Cultivating Citizens: Suzhi (Quality) Discourse in the PRC. Positions: East Asia Cultures Critique 17(3): 523-535.

33. Knapp Ronald G, Kai-Yin Lo (2005) House Home Family: Living and Being Chinese - Spatial Habitus: Making and Meaning in Asia's Vernacular Architecture, University of Hawaii Press, Hawaii, United States

34. Yan Fei (2005) Education Problems with Urban Migratory Children in China. Journal of Sociology \& Social Welfare 32(3).

\begin{tabular}{|l|}
\hline \multicolumn{1}{|c|}{ Your next submission with Juniper Publishers } \\
will reach you the below assets \\
- Quality Editorial service \\
- Swift Peer Review \\
- Reprints availability \\
- E-prints Service \\
- Manuscript Podcast for convenient understanding \\
- Global attainment for your research \\
- Manuscript accessibility in different formats \\
( Pdf, E-pub, Full Text, Audio) \\
- Unceasing customer service \\
Track the below URL for one-step submission \\
https://juniperpublishers.com/online-submission.php
\end{tabular}

DOI: 10.19080/ASM.2020.05.555654 